\title{
A Study on the Role-Play in Chinese Reading Teaching in Elementary School
}

\author{
Min Tian, Jumei Xiao \\ Huzhou Teachers College, Zhejiang, China
}

\begin{abstract}
In the course of Chinese reading teaching in elementary school, role-play can give full play to students' main position, improve students' cognitive level, enhance students' language application ability, and accelerate students' affective interaction with roles in the text. So that boost the elementary school Chinese reading teaching level, teachers should select appropriate texts for role-playing, carry out pre-class preparation and post-class evaluation to carry out role-playing.
\end{abstract}

Keywords: role-playing, elementary school Chinese reading, reading strategies

\section{Role-Playing and Primary School Chinese Reading}

"Role" usually refers to the role of an actor in a play or novel. Due to the transfer of knowledge in modern society, the word "role" is gradually introduced into teaching, thus forming the teaching strategy of role-playing. The meaning of role-play in teaching is to carry out teaching in the form of sketches or plays, which can provide students with real situations, so as to present the teaching content vividly. At this time, the identity of students becomes "actor" and "audience", so that students are more likely to be involved in the classroom (Yang, 2014, p. 81). Role-playing in primary school Chinese reading teaching requires students to have a preliminary understanding of the text and the characters (Liu, 2008). Students play the characters in the text and show the story completely, which is a piece or play completed by many students. In the process of acting, students can experience the emotion and inner world of characters more deeply through a series of actions and words, and form correct values. If role-playing is introduced into primary school Chinese reading teaching, reading an article becomes appreciating a play, which can experience the feelings of the authors and the thoughts and feelings of each role in the article. At the same time, in the process of teaching, the identity of students has changed greatly, from the identity of readers and onlookers to the "dramatists", which can give full play to the main position of students. It is of great help to improve the cognitive level, the ability of language application and the dialogue between the students and the characters in the text.

\section{Role-Playing in Primary School Chinese Reading Teaching}

Role-play can give full play to students' main position, improve students' cognitive level, improve students' language application ability, and enhance the emotion of text and characters.

Min Tian, M.A., College of Teacher Education, Huzhou Teachers College.

Jumei Xiao, Ph.D., associate professor, College of Teacher Education, Huzhou Teachers College. 


\section{Give Full Play to the Dominant Position of Students}

The new round of basic education curriculum reform clearly requires that teachers should actively interact with students in the classroom during the teaching process, and students should actively and individually learn. At this time, the identity of teachers becomes a mentor, which promotes the development of every student. Primary school Chinese reading is very storytelling. Teachers should make full use of this feature to encourage students to play the role in the text. In this process, teachers should guide students, so as to assign good roles and give them certain autonomy when students choose roles. Students can also adapt the content of the text according to their own understanding in this process students can have a direct dialogue with the characters in the text, construct knowledge independently, and then achieve the understanding of the text. For example, when teaching the text "Little Tadpole Looking for His Mother", the teacher can first lead the students to understand the whole text; secondly, encourage the students to play the roles of "mother carp”, "turtle”, "mother frog”, and "Little Tadpole" in the text, and make the role assignment; then, let the students go home to prepare some props, such as some headdresses; and finally, the students can report their achievements are performed in class. Other students can comment on their performances as small judges. In the whole teaching process, every student is involved in the classroom, which not only mobilizes the classroom atmosphere, but also gives full play to the main position of students.

\section{Improve Students' Cognitive Level}

The so-called "cognition” refers to the individual's psychological activities, such as perception, memory, thinking, imagination, speech, and attention in the process of understanding things. Cognitive development refers to the development of children's psychological representation of the world and the way of thinking about the world. There will be many rational texts in Chinese reading teaching in primary schools, including some ideas that the author wants to express (Xu, 2018, p. 312). To improve students' cognitive level is one of the important tasks in primary school Chinese teaching. In the reading teaching of primary school Chinese, the students can quickly understand the implied cognitive value of the text by role-playing, so as to improve their cognitive level. For example, when teaching the lesson "A Simple and Useful Person", the teacher can let the students preview the text first, and then let the students play the roles of "mother", "father", "elder sister", "elder brother", and "I" in the text. The students will present the whole story in class, so that the students will have a deep understanding of the truth in the text. After the performance, the teacher can ask the students, "What kind of person do you want to be when you grow up?" The student replied, "People like peanuts". The teacher continued to ask, "What kind of person is a peanut like person? Who can say specifically?" Some students will also answer, "Be a person who contributes to the society, and be a useful person”. The teacher asks, “Are there people like peanuts in our life?” Students replied, “There are, for example, unknown sanitation workers”. Some students replied, “There are soldiers guarding the border of the motherland”. Through students' performances and teachers' questions, students can understand what kind of person to be, comparing with their current life ideals, understand the truth of being a person, and then improve students' cognitive level.

\section{Improve Students' Language Application Ability}

Learning the application of language is one of the basic tasks of Chinese teaching. It is a problem we need to pay attention to improve the language application ability of primary school students. One of the most important is to provide students with a lively and relaxed learning atmosphere, so that students are brave and willing to express. Role-play is the best way to mobilize the classroom atmosphere. In role-play, they can enjoy 
the happiness that the role can bring to them. Teachers should pay attention to the needs of students and try to let students reproduce the content of the text as much as possible. In this process, students' language materials are enriched and learn to use different ways to correct to express one's own opinions in a correct way improves one's ability of language application. For example, when teaching the lesson "Traveling in a Cow's Stomach”, the teacher can show the dialogue between red head and green head on the courseware. Who said these words? What did you say? Under what circumstances? In what tone? Can show the words for students to role-play, let students experience red head desperately cry for help, red head crying I will die, red head sad to say, but what do you say to me?, red head said thank you in a low voice, after the success came out of the cow's stomach, he was happy to say thank you to green head in tears, in different situations, red head expressed different feelings when speaking. After the analysis, students can play the roles of "red head" and "green head" according to their understanding of the text, experience different language expressions in different situations, and improve their language application ability.

\section{Improve the Emotional Communication Between Students and the Characters in the Text}

In primary school Chinese teaching, emotional education is not only an important teaching goal, but also an important guarantee for the implementation of primary school Chinese teaching. The subject of Chinese has the characteristics of education, which needs to be promoted by students' emotions and students' understanding of the text needs to be based on emotions. The cultivation of emotion cannot be separated from teaching activities, which requires teachers to create teaching scenarios, such as using audio and pictures, so that students can accurately grasp the content of the text, and then students can play different roles to present the content of the text, so that the characters in the textbook can have spiritual collision and emotional resonance with the students, can go deep into the author's inner world, and experience the feelings expressed in the article Love. For example, when teaching the lesson "The Sparrow", the teacher asks the students to read through the text first and then carefully realizes that the boy says: "No, I didn't see it”. Lenin said, "It must have flown away or frozen to death. He is afraid of the cold weather". Lenin said, "What a beautiful Sparrow! It's a pity that it will never come back”. From these words, we can see Lenin's love for larks. In the second half of the text, through Lenin's step-by-step guidance and education of the boy, the sparrow finally came back. In the whole process, Lenin did not blame the boy, but showed his patience and respect for the ingenious education methods, at the same time, the boy also showed a sense of guilt. In this process, the teacher can take the illustrations in the text as the situation, and let the students play the role. In the process of playing, the teacher can experience the boy's guilt and Lenin's earnest teaching.

\section{The Application Strategies of Role-Playing in Primary School Chinese Reading Teaching}

The fables and the little things in life can be presented by role-playing to deepen students' understanding of the text. So, how to use role-play in primary school Chinese reading? Generally speaking, we should select the appropriate text, prepare for the selected text, and give students feedback.

\section{Select the Text and Mobilize the Classroom Atmosphere}

Not all texts are suitable for role-playing teaching. For example, the teaching of "Pinyin" in the lower grades generally adopts the teaching method. The teaching of "Pinyin" is the basic learning and the premise of learning the follow-up knowledge. The age of the students is still young, the basic knowledge is not solid enough, the language expression ability has not developed to a certain level, so the role-playing method is not 
suitable for use here. For example, the fifth grade text "The Sun" is an expository text, its purpose is mainly to introduce the important role of the sun in our lives, so that students can understand that we cannot live without it the sun, this kind of article tends to introduce some declarative knowledge to students, and the method of role-playing is not applicable here. For example, some texts describing the great mountains and rivers of China, Guilin scenery is the best in the world, which is to let students appreciate the great mountains and rivers of our country, appreciate the characteristics of "strange", "beautiful”, and "dangerous" mountains of Guilin, and the characteristics of "quiet”, "clear”, and "green” water of Guilin. This kind of text is not suitable for role-playing. Role-play is suitable for the dialogue of characters in texts, and different characters express different feelings, such as fable story and some small things in life. Most of these texts are in the form of dialogue, with rich story plots, For example, “A simple and useful person”, “Little Tadpole Looking for mother”, "traveling in the belly of a cow", and "lark" can use role-playing methods. In teaching, teachers can pay attention to the texts that can be played by role-playing methods, encourage students to play the characters boldly, mobilize the atmosphere of the classroom, and improve the quality of teaching.

\section{Pre-class Preparation for Teaching Objectives}

The preparation before class mainly includes the preparation of props, the choice of students and the rehearsal before class. As for the preparation of props, we take the lesson "Little Tadpole Looking for Mother" taught by the teacher as an example. There are four roles in the lesson: "mother carp”, "turtle”, "mother frog”, and "Little Tadpole", which requires students to be able to distinguish the above roles. Because the teaching object is the second grade students, the teacher can assign the role and prepare the props by the students themselves, such as preparing some headwear according to the characteristics of the role. In the process of preparation, middle school students realized the characteristics of "mother carp", "turtle", "mother frog", and "Little Tadpole", and expanded their natural science knowledge.

In terms of students' choice, role-play is very important for students' choice. For those shy children, they are ashamed to show themselves. At this time, teachers should give them more encouragement, confidence, and courage to show. At the same time, we should also do a good job in the role allocation. For example, when the teacher teaches the lesson "A Simple and Useful Person”, the roles include "mother”, “father”, “elder sister”, "elder brother", and "I". The teacher should assign different roles according to the understanding of the students. For example, the lively students can play the role of "I" in the ordinary classroom. The contemplative students can play the role of "father" etc., so that students can show their true feelings and feel the characters in the text better. When choosing students to perform, we should try our best to give every student a chance to enjoy the performance. In addition, in the role-playing, the students should be able to use their spare time to rehearse and have different understanding of the characters in the rehearsal process. At the same time, in rehearsal, we should also remind students to pay attention to the time of performance. It is better to control it in about 10 minutes to reduce the burden of students. It should be noted that in addition to the students who need to perform before class, other students do not review before class. The purpose of doing this is not only to avoid the preconceived concept, but also to achieve the teaching goal.

\section{After Class Evaluation to Deepen Students' Understanding}

When the class performance is over, the whole class students and teachers should comment and summarize the performance, praise the students for their good work, and point out the areas that students need to improve, so that students can know their learning results in time. After class evaluation can give students 
important feedback information. Only when students get feedback information, know where they are doing well, and where they are doing well, can they develop their strengths and avoid weaknesses in the next role-play, and get the best development. At the same time, students can have a deeper understanding of the text in the process of evaluation. For example, this article "Sparrow", ask students questions, if you are a boy, Lenin's question, "How do you answer?” If you are Lenin, "How do you enlighten the boy?" and so on. By asking students questions, we can help them to clarify the context of the text, and then achieve the understanding of the text. For another example, in the lesson "traveling in a cow's stomach", first ask the students who watch the performance. If you are red head, what do you think at this moment? If you are green head, how do you plan to save your little partner red head? First, the students answer, and then the performers answer. By comparing the similarities and differences among their answers, the text content is elaborated in detail to deepen the students' understanding of the text. Another example is the lesson "Falling Flower". First of all, ask the students who watch the performance. What kind of people do you want to be when you grow up by watching the performance? Why do you want to be such a person? Please say your reasons. Then, ask the performing students, "What kind of person you want to be through the performance?" and explain, "Why you want to be such a person”. After questioning the students, compare the similarities and differences of their answers, and sort out the text properly, so as to clarify the thinking of the students on this article.

In a word, the method of role-playing is one of the most important magic weapons in the teaching of Chinese reading in primary schools. In the classroom, the method of role-playing is used to mobilize the atmosphere of the classroom, and students' interest in learning Chinese will be greatly increased. Students can really participate in the teaching of Chinese classroom and make the classroom full of vitality. In this process, students should also realize that we have to play a lot of roles in life, and each role has our own responsibilities. In the process of role-playing, it is very helpful for their future life to recognize their obligations by exchanging roles. Finally, in the process of application, we should pay attention to mobilize the enthusiasm of students to ensure that every student in the class can participate in. At the same time, we should understand the skills and methods of role-playing and do a good job in preparation, so as to optimize the role-playing in primary school Chinese Reading teaching.

\section{Conclusion}

To sum up, through exploring the relationship between role-playing and primary school Chinese reading, we can find that role-playing can give full play to students' subject status, improve students' cognitive level, improve students' language application ability, and enhance students' emotion with the text. In order to better reflect the value of role-playing in primary school Chinese reading teaching, teachers should select appropriate texts, be prepared for the selected texts and give students feedback, so as to make primary school Chinese reading teaching more interesting. Through role-playing, students can also better feel others' thoughts and feelings, which is very helpful for the cultivation of students' empathy ability. Therefore, teachers should excavate the intrinsic ideological value of the text in teaching. Students can more deeply understand the connotation of the text by exchanging roles, so as to achieve their own situation, so that students' emotions can be sublimated.

\section{References}

Hu, D. Z. (2015). The application of situational simulation and role-playing in Chinese teaching in primary schools. Curriculum Education Research, 25, 41.

Liu, H. (2008). Research on the teaching strategy of “role assignment”. Nanjing: Nanjing Normal University. 
$\mathrm{Xu}, \mathrm{Y}$. (2018). 333 analysis of comprehensive examination oriented Education (p. 312). Beijing: Beijing University of Technology Press.

Yang, K. (2017). On the application of role-playing method in primary school Chinese teaching. Chinese out of School Education, $21,20$.

Yang, Y. M. (2014). Narrowing the distance in role-playing-On the role of role change in primary school Chinese teaching. Chinese out of School Education, 23, 81.

Zhang, C. Y. (2017). Role-playing as a skillful assistant for Chinese reading. Masters Online, 23, 10-11. 